\title{
Tłumaczenie w programie CAT z podglądem translatora: chwilowa fascynacja czy przyszłość tlumaczeń pisemnych?
}

MT-assisted TM translation: the future of translation or just a fad?

\author{
Maria NIKISHINA \\ Uniwersytet Warszawski/ University of Warsaw \\ E-mail: m.nikishina@uw.edu.pl,
}

\begin{abstract}
TM (translation memory) and MT (machine translation) were perceived as opposite approaches to using technology in translation - the aim of TM used in CAT tools is to optimise translation workflow and the initial aim of MT is to replace a human translator. In the last years CAT tools began to implement MT giving translators additional suggestions. As a result the translator can edit both TM matches and MT output within a single CAT tool. This article is devoted to such a phenomenon. It addresses technologies used in machine translation and computer-assisted translation, explores differences between them and provides an insight into MT-assisted TM translation and post-editing which had been known first. It also presents a brief overview of the most curious findings in the field.
\end{abstract}

Keywords: computer-assisted translation, CAT tools, machine-human translation, post-editing, machine translation, MT-assisted TM translation, MT-enhanced computer assisted translation

\section{Wstęp}

Relatywnie niedawno w branży tłumaczeniowej pojawił się nowy nurt, mający zoptymalizować pracę tłumacza, a mianowicie jednoczesne korzystanie z pamięci tłumaczeniowej i tłumaczenia maszynowego. Stało się to możliwe stosunkowo niedawno, ponieważ dopiero teraz nowe technologie sprawiły, że w wyniku redagowania tłumaczenia maszynowego powstaje tekst, który można potem wykorzystać ${ }^{1}$. W niniejszym artykule mam zamiar opowiedzieć o podstawowych pojęciach, które zazwyczaj rozróżnia się w kwestii wykorzystania technologii w tłumaczeniu pisemnym - chodzi o tłumaczenie maszynowe i tłumaczenie wspomagane komputerowo. Chciałabym omówić nowy trend w tłumaczeniach pisemnych, który jest w zasadzie połączeniem tych dwóch technologii, a mianowicie tłumaczenie w programie CAT z podglądem tłumaczenia maszynowego, i zwrócić uwagę na niektóre, w mojej opinii, najbardziej interesujące rozważania badaczy dotyczące tego typu thumaczeń.

${ }^{1}$ Oczywiście kiedyś także można było redagować tłumaczenie maszynowe, ale czasami poświęcano na to więcej czasu niż na thumaczenie od zera, więc to po prostu było nieopłacalne. 
Zostanie również wspomniana postedycja, czyli stricte redagowanie thumaczenia maszynowego.

\section{Tłumaczenie maszynowe a thumaczenie wspomagane komputerowo}

Zazwyczaj wyróżnia się dwa pojęcia - tlumaczenie maszynowe (ang. Machine Translation, MT) i ttumaczenie wspomagane komputerowo (czasami nazywane Computer-Aided Translation/ Computer-Assisted Translation). Tłumaczenie maszynowe jest thumaczeniem automatycznym wygenerowanym przez program powszechnie nazywanym translatorem (najbardziej znany przykład to Tłumacz Google). Thumaczenie wspomagane komputerowo jest natomiast thumaczeniem wykonanym przez ,żywego" tłumacza przy pomocy odpowiedniego programu, tzw. narzędzia CAT (ang. CAT tool), które często jest również nazywane programem, narzędziem wspomagającym tłumaczenie lub aplikacją (por. Ł. Bogucki 2009). Oczywiście $\mathrm{w}$ założeniu tłumacz może również korzystać $\mathrm{z}$ innych narzędzi komputerowych (np. korpusów), ale chciałabym skupić się właśnie na programach CAT. Innymi słowy, tłumaczenie maszynowe implikuje maszynę (która w założeniu ma na celu zastąpienie człowieka), czyli komputer, który samodzielnie generuje thumaczenie. Natomiast thumaczenie wspomagane komputerowo implikuje thumacza, czyli jest tylko narzędziem pomocniczym.

Podstawową funkcją takich programów jest zapamiętywanie już przetłumaczonych par, które mogą zostać później wykorzystane. Takie pary nazywają się segmentami i najczęściej są odpowiednikami zdań. Niekoniecznie jednak segment musi być całym zdaniem, szczególnie jeśli chodzi o thumaczenie tabeli lub prezentacji. Segmenty są przechowywane w pamięci thumaczeniowej (TM, z ang. Translation memory). Istnieje również możliwość zapamiętywania przetłumaczonych par na poziomie wyrazów (terminów): tzw. baza terminologii (TB, z ang. Termbase) przechowuje thumaczenia i ewentualnie definicje terminów. Ze względu na te funkcje programy CAT najlepiej się sprawdzają w tłumaczeniu tekstów specjalistycznych, podobnych do siebie, a nie np. literackich czy wymagających kreatywnego podejścia.

Pamięć tłumaczeniowa działa w następujący sposób: w przypadku znalezienia w niej segmentów podobnych do thumaczonych wcześniej (tzw. trafień, z ang. matches) program wyświetla kilka propozycji (z najbardziej zbliżonym na pierwszym miejscu) oraz zaznacza różnice pomiędzy bieżącym segmentem a trafieniem. Oprogramowanie określa również stopień podobieństwa znalezionego segmentu (np. 100\%, 75\% itd). 100-procentowe trafienia uważa się za tzw. perfect match znaczy to, że w pamięci thumaczeniowej znaleziono identyczny segment, który już został przetłumaczony. Trafienia 99-75\% nazywają się fuzzy match, czyli trafieniami rozmytymi; znaczy to, że w pamięci thumaczeniowej znaleziono podobny segment, ale thumacz musi go zredagować. Chciałabym zaznaczyć, że jest to podział przykładowy i zależy on od programu oraz często od podejścia klienta lub biura tłumaczeńn ${ }^{2}$.

\footnotetext{
${ }^{2}$ Podział ten ma znaczenie dla wyceny thumaczenia.
} 
Może on być np. 99-60\% (zob. Ł. Bogucki 2009). Tłumacz często może samodzielnie ustalić podział w programie, z którego korzysta. W programie zazwyczaj można również ustalić próg wyświetlania trafień z pamięci thumaczeniowej (np. powyżej $75 \%$ ), ponieważ często podobieństwo segmentów jest zbyt niskie i thumaczenie od zera jest szybsze od naniesienia poprawek. Jeśli w pamięci tłumaczeniowej nie znaleziono trafienia, segment otrzymuje status „,no match", czyli brak trafienia.

Jak już zostało wspomniane, zapamiętywanie już przetłumaczonych par jest najważniejszą funkcją programów CAT, dzięki której tłumacz może pracować szybciej. Dlatego niektórzy badacze (np. Ł. Bogucki 2009: 52, O. Witczak 2016: 206) zaliczają do programów wspomagających tłumaczenie zwykłe edytory tekstu (takie jak Microsoft Word) czy elektroniczne słowniki i glosariusze; w niniejszym artykule omawiam jednak stricte programy wykorzystujące technologię pamięci thumaczeniowej. Chciałabym tylko zaznaczyć, że narzędzia CAT oprócz wspomnianej pamięci thumaczeniowej oferują również dodatkowe funkcje usprawniające pracę thumacza: zachowanie formatowania tekstu wejściowego przy pomocy tzw. tagów, stworzenie pamięci tłumaczeniowej poprzez zestawienie już przetłumaczonych tekstów (tzw. aligning), ekstrakcję terminów, tworzenie glosariuszy oraz korpusów. Koordynatorzy projektów i weryfikatorzy również korzystają z narzędzi CAT, ponieważ poprzez funkcję analizy projektu i możliwość delegowania zadań usprawniają one zarządzanie projektami i pracę $\mathrm{w}$ zespole; ponadto bardzo często programy CAT oferują oddzielny tryb weryfikacji i korekty. Oprócz tego w oprogramowaniu można wykonywać takie typowe czynności jak: edycja tekstu, wyszukiwanie i zamienianie oraz wyszukiwanie w pamięci tłumaczeniowej (tzw. concordance) wcześniej przetłumaczonych pojedynczych słów i fraz. Programy CAT sprawdzają również pisownię, a niektóre mają funkcję autouzupełniania wyrazów.

Co ciekawe, z perspektywy historycznej programy CAT są ,produktem ubocznym" próby stworzenia narzędzia, które potrafi wykonać pracę za tłumacza - thumacza maszynowego. Dlatego historia programów CAT i historia thumaczeń maszynowych są nieodłącznie związane ze sobą. Pierwsze próby wykorzystania maszyn do tłumaczenia podjęto w latach 30 . XX wieku. Pierwszych systemów do tłumaczeń maszynowych w latach 50. używano do thumaczeń rosyjsko-angielskich; w 1954 po raz pierwszy publicznie zaprezentowano system thumaczenia maszynowego, który automatycznie przetłumaczył ponad 60 zdań z rosyjskiego na angielski w oparciu o słownik liczący 250 słów. Stworzenie systemu thumaczenia automatycznego, który byłby w stanie zastąpić człowieka, okazało się dużym wyzwaniem i dlatego podjęto próbę stworzenia narzędzi pomocniczych dla tłumacza. Pierwsze propozycje dotyczące optymalizacji procesu thumaczenia pojawiły się jeszcze w latach $60 .-70$., w tym pomysł wykorzystania archiwum thumaczeń (szerzej na ten temat zob. J. Hutchins 1998). W latach 80 . pojawiły się pierwsze narzędzia CAT, które stały się dostępne na rynku od lat 90 .

Nie omawiam tu stricte technologii thumaczenia maszynowego. Chciałabym tylko zaznaczyć, że istnieje kilka metod, tzn. typów systemów tłumaczenia maszynowego. Pierwsze systemy były oparte na słownikach i regułach, a w latach 90 . została wprowadzona metoda statystyczna, czyli thumaczenie maszynowe w oparciu o kor- 
pusy, które dotychczas jest skutecznie używane ${ }^{3}$. Na początku XXI wieku podjęto pierwsze próby używania metod uczenia maszynowego (machine learning) do tłumaczeń maszynowych. Przełom jednak nastąpił niedawno: w roku 2016 Google ogłosił ${ }^{4}$, że jakość tłumaczeń maszynowych opartych na sieciach neuronowych w niektórych parach językowych jest porównywalna do thumaczeń profesjonalnych i że tzw. system Neural Machine Translation wprowadzono do thumacza Google. Chciałabym zaznaczyć, że jest to najbardziej znany, ale nie jedyny system oparty na sieciach neuronowych; np. w środowisku tłumaczy dużą popularnością cieszy się system DeepL. Tłumaczenie oparte na sieciach neuronowych ma swoje wady i zalety $\mathrm{w}$ porównaniu do tłumaczeń statystycznych; tłumaczom zaleca się zapoznanie $\mathrm{z}$ charakterystycznymi dla obu systemów niedociągnięciami.

Wiele programów CAT oferuje możliwość podglądu thumaczenia maszynowego, czasami pochodzącego $\mathrm{z}$ różnych silników. O tym, jak to zmienia proces thumaczenia pisemnego, opowiem w dalszej części artykułu.

\section{Tłumaczenie w programie CAT z podglądem translatora - o istocie i korzy- ściach jego stosowania}

Tradycyjnie te dwie technologie - pamięć thumaczeniowa i thumaczenie maszynowe - były uważane za odrębne, ponieważ, jak zostało zaznaczone w p. 2, mają one różne cele: thumaczenie maszynowe jest wykonane automatycznie i pierwotnie miało zastąpić tłumacza, natomiast pamięć tłumaczeniowa jest narzędziem pomocniczym i thumaczenie w programie CAT musi zostać wykonane przez tłumacza. Obecnie te dwie technologie zaczęły się do siebie upodabniać ${ }^{5}$. Dzieje się tak dlatego, że w dzisiejszych czasach jednym z głównych nurtów w branży tłumaczeniowej jest połączenie możliwości thumaczenia maszynowego i programów wspomagających thumaczenie dla optymalizacji pracy thumacza (tzn. jednoczesne korzystanie z pamięci tłumaczeniowej i thumaczenia maszynowego). Jest to thumaczenie segmentów, które nie mają trafień w pamięci thumaczeniowej (czyli segmentów z kategorii ,no match") przez translator wbudowany do programu CAT, co skutkuje sytuacją, w której tłumacz redaguje zarówno wynik tłumaczenia maszynowego, jak i podpowiedź $\mathrm{z}$ pamięci tłumaczeniowej $\mathrm{w}$ ramach jednego programu CAT. Tłumacze mają wtedy dodatkowe podpowiedzi oprócz tych, które pochodzą z pamięci thumaczeniowej i mogą z nich korzystać jako z punktu odniesienia.

Jak już zostało wspomniane, w większości przypadków tłumacz może sam ustalić $\mathrm{w}$ programie, poniżej jakiego progu podpowiedzi z pamięci tłumaczeniowej są uważane za brak trafienia (,no match”). Można zatem także mieć segmenty przethumaczone maszynowo niezależnie od tego, czy w pamięci tłumaczeniowej znaleziono trafienia pasujące do tych segmentów. Warto również podkreślić, że trafienia $\mathrm{z}$ pamięci thumaczeniowej i podpowiedzi $\mathrm{z}$ translatora $\mathrm{w}$ programie wspomagającym

\footnotetext{
${ }^{3}$ Istnieją również tzw. systemy łączące kilka metod.

${ }^{4}$ https://ai.googleblog.com/2016/09/a-neural-network-for-machine.html.

${ }^{5}$ Więcej na ten temat p. S. O’Brien/ J. Moorkens (2014: 1-2) oraz C. Teixeira (2013: 305).
} 
thumaczenie nie wyglądają tak samo. Program CAT zaznacza różnice pomiędzy bieżącym segmentem a trafieniem z pamięci thumaczeniowej oraz podaje stopień podobieństwa. Natomiast podpowiedź z translatora jest wyświetlana beż żadnych adnotacji. Tłumacz także widzi, z jakiej pamięci tłumaczeniowej pochodzi podpowiedź i może zdecydować, czy jej ufa.

W literaturze anglojęzycznej, a tym bardziej polskojęzycznej, nie ma nawet jednoznacznego terminu oznaczającego tę czynność (chodzi o jednoczesne korzystanie z pamięci thumaczeniowej i translatora). Używa się terminów „machine translation enhanced computer assisted translation" (,MT-enhanced computer assisted translation”) oraz „,MT-assisted TM translation". Ten ostatni podkreśla połączenie dwóch technologii - pamięci tłumaczeniowej i tłumaczenia maszynowego. Można także spotkać nazwę „tłumaczenie hybrydowe” w odniesieniu do tekstów, które zostały przetłumaczone za pomocą kilku metod ${ }^{6}$, tzn. przez thumacza przy użyciu translatora i pamięci tłumaczeniowej. Nie należy go mylić z hybrydowym tłumaczeniem maszynowym - „hybrydowy” tu, to typ thumaczenia maszynowego.

Ze względu na to, że zazwyczaj badacze zwracają uwagę na odróżnienie thumaczenia maszynowego od thumaczenia wspomaganego komputerowo (np. zob. Ł. Bogucki 2009, O. Witczak 2016), można podążając tym tokiem rozumowania dla potrzeb teoretycznych rozróżnić tłumaczenie wspomagane komputerowo i wspomagane maszynowo (nie tożsame z tłumaczeniem maszynowym, tzn. automatycznym), chociaż ostatnie jest de facto również tłumaczeniem wspomaganym komputerowo, ponieważ jest wykonywane $\mathrm{z}$ wykorzystaniem programu komputerowego.

Norma ISO 17100:2015 „Usługi thumaczeniowe. Wymagania dotyczące świadczenia usług thumaczeniowych" rozróżnia postedycję i thumaczenie z podglądem tłumaczenia maszynowego. Zgodnie $\mathrm{z}$ nią postedycja polega na edytowaniu i poprawieniu tekstu przetłumaczonego maszynowo (automatycznie); nie dotyczy to sytuacji, kiedy tłumacz widzi podpowiedź silnika tłumaczenia maszynowego podczas thumaczenia w programie CAT i korzysta z niej jak z pamięci tłumaczeniowej. Warto podkreślić, że norma ISO 17100:2015 nie określa zasad korzystania z programów $\mathrm{CAT}$, a tym bardziej $\mathrm{z}$ podglądu thumaczenia maszynowego $\mathrm{w}$ tych programach. Więcej na temat postedycji zob. p. 5 .

\section{Spojrzenie teoretyczne i empiryczne na thumaczenie w programie CAT z podglądem translatora}

Pierwsze uwagi dotyczące tego, że thumaczenie wspomagane komputerowo powinno być oparte nie tylko na pamięci thumaczeniowej, ale również na tłumaczeniu maszynowym, padały ponad 10 lat temu, chociaż postedycja pojawiła się wcześniej. W artykule, który ukazał się w 2009 r., I. Garcia wskazuje na możliwość użycia połączenia pamięci tłumaczeniowej i tłumaczenia maszynowego po pojawieniu się nowego silnika thumaczenia statystycznego Google w marcu 2008 r. Zgodnie z nim

${ }^{6}$ K. Bundgaard 2017: 15; https://lilt.com/. [Dostęp 10.02.2018]. 
właśnie wtedy uznano, że tłumaczenie maszynowe jest na takim poziomie, na którym już może pomóc tłumaczowi.

W 2013 r. charakteryzując nowe nurty w branży tłumaczeń C. Teixeira (2013: 305) również wskazał na to, że pamięci thumaczeniowe i podpowiedzi z translatora są bardzo do siebie podobne $\mathrm{z}$ punktu widzenia osoby, która $\mathrm{z}$ nich korzysta $\mathrm{w}$ ramach jednego narzędzia $\mathrm{CAT}^{7}$. Jeśli nawet podpowiedź translatora nie satysfakcjonuje w pełni tłumacza, zawsze może on ją wykorzystać jako punkt odniesienia. Jako pierwsze środowisko dla thumaczy łączące możliwości pamięci thumaczeniowych $\mathrm{z}$ thumaczeniem maszynowym C. Teixeira wymienił program Google Translator Toolkit. Program ten zdaje się być nieczęsto używany przez thumaczy albo nawet im nieznany. Umożliwia on jednoczesne korzystanie $\mathrm{z}$ dostępnych pamięci tłumaczeniowych i thumacza Google. W tym artykule C. Teixeira wskazuje na to, że postedycja, czyli thumaczenie wykonywane na bazie thumaczenia maszynowego, była używana od pewnego czasu, ale bez korzystania z pamięci tłumaczeniowej.

Zachodzi zatem pytanie o konieczność rozróżnienia na poziomie teoretycznym postedycji i thumaczenia w programie CAT z podglądem translatora. K. Bundgaard powołując się na S. O’Brien i C. Teixeira dochodzi do wniosku, że nie jest to do końca sensowne, ponieważ w obu przypadkach tłumacz zajmuje się de facto redagowaniem podpowiedzi, niezależnie od tego, czy pochodzą one z pamięci tłumaczeniowej, czy z translatora (K. Bundgaard 2017: 15) ${ }^{8}$. Często w odniesieniu do procesu thumaczenia w programie CAT z uruchomionym silnikiem thumaczenia maszynowego używa się terminu „postedycja” (np. A. Guerberof Arenas/ H. Depraetere/ S. O’Brien 2012; Matecat. Final Report 2014), chociaż, jak już zostało wspomniane, wytyczne je rozróżniają.

Jeśli chodzi o wyniki badań empirycznych, to ich podsumowanie jest w pewnym sensie uogólnieniem dlatego, że te badania były różnie konfigurowane, dotyczyły różnych kombinacji językowych, różnych programów CAT itd. Można jednak stwierdzić, że obecnie korzystanie z translatora, w tym wbudowanego w narzędzie CAT, jest szybsze niż thumaczenie „od zera”. Dla thumacza nie ma znaczenia, czy redaguje on tłumaczenie maszynowe dobrej jakości czy trafienie z pamięci thumaczeniowej (w obu przypadkach jego zadanie polega na zestawieniu tekstu źródłowego i podpowiedzi), a są nawet podstawy, żeby stwierdzić, że redagowanie podpowiedzi z pamięci thumaczeniowej oraz thumaczenia maszynowego w ramach jednego programu może być tak samo, a nawet bardziej wydajne niż thumaczenie tylko na podstawie pamięci thumaczeniowej (zob. A. Guerberof Arenas/ H. Depraetere/ S. O'Brien 2012: 212-213).

Zgodnie $\mathrm{z}$ wynikami badań prowadzonych $\mathrm{w}$ ostatnich latach programy CAT, które mają wbudowane silniki tłumaczenia maszynowego, teraz coraz bardziej zyskują na popularności, a tłumacze częściej korzystają z trafień zarówno z pamięci

\footnotetext{
${ }^{7}$ Według C. Teixeira to podejście dotyczy przede wszystkim zawodowych thumaczy.

${ }^{8}$ Tak samo w przypadku tłumaczenia wspomaganego komputerowo: niektórzy badacze krytykują tę nazwę, ponieważ tłumaczenie pisemne w dzisiejszych czasach zawsze jest w pewnym stopniu wspomagane komputerowo (zob. np. A. Pym 2010: 123).
} 
thumaczeniowej, jak i podpowiedzi thumaczenia maszynowego, co bardzo często cechuje się też wysoką wydajnością (zob. Matecat. Final Report 2014: 2, C. Teixeira 2014: 45; A. Guerberof Arenas 2014: 165). W artykule, który ukazał się w 2016 r., T.P. Christensen i A. Schjoldager (2016: 89) zaznaczyły, że korzystanie $\mathrm{z}$ zaawansowanych systemów, w których są dostępne nie tylko pamięci thumaczeniowe i zarządzanie terminologią, ale również thumaczenie maszynowe, jest koniecznością ze względu na realia rynku thumaczeń. Wykorzystanie translatora jako narzędzia pomocniczego $\mathrm{w}$ pracy thumacza jest jednak tematem kontrowersyjnym (zob. S. O’Brien 2012: 11-12). Wyobrażenie o tym, czy rzeczywiście thumacze korzystają z translatorów mogą dać nam fora thumaczy. Na forach proz.com ${ }^{9}$ thumacze dyskutują na temat używania translatora i strategii korzystania z niego; przyznają się oni do korzystania z translatorów jako „punktu odniesienia” oraz narzędzia przyśpieszającego pracę (jako autouzupełnianie wyrazów). Znaczy to, że chociaż nie ma jednoznacznej nazwy czy definicji tej czynności, istnieje ona w codziennej pracy thumacza.

\section{Postedycja}

Tradycyjnie poprawianie przez tłumacza tekstu, który został przetłumaczony automatycznie, nazywa się postedycją ( $\mathrm{z}$ ang. post-editing/postediting). Redaktor podczas wykonywania postedycji pracuje z tekstem źródłowym, który został wstępnie przetłumaczony automatycznie, zgodnie ze specyficznymi wytycznymi (definicja S. O’Brien 2011: 1). Jak już zostało wspomniane, norma ISO 17100:2015 rozróżnia postedycję i thumaczenie z podglądem thumaczenia maszynowego. Zasady postedycji reguluje oddzielna norma (ISO 18587:2017).

Zgodnie $\mathrm{z}$ najbardziej rozpowszechnionym założeniem (oraz normą 18587:2017) są dwa rodzaje postedycji: szybka edycja tekstu (terminy angielskie to: fast/ gist/ rapid/ light post-editing), która ma na celu uczynić go zrozumiałym po niezbędnych poprawkach, oraz ,pełna” (conventional/ full), która ma na celu stworzenie tekstu o lepszej jakości (tzw. publishable quality). Czynności wykonywane przez reaktorów różnią się w zależności od typu wejściowego tekstu i celów tekstu wyjściowego, ale głównym założeniem jest to, że redagowanie tłumaczenia maszynowego powinno być mniej pracochłonne niż tłumaczenie „od zera”.

W roku 2017 ukazała się wspomniana norma ISO 18587:2017 dotycząca postedycji. We wprowadzeniu autorzy wskazują na rozpowszechnienie korzystania z tłumaczeń maszynowych, które czasami jest jedyną opcją dla projektów z ograniczonym budżetem lub projektów, które trzeba pilnie zrealizować. Według autorów na razie nie ma systemu, który mógłby zastąpić profesjonalnego tłumacza, więc zachodzi potrzeba kształcenia kompetentnych specjalistów od postedycji. Warto zaznaczyć, że we wprowadzeniu wskazano na wydajność i szybkość tłumaczeń maszynowych oraz na zwiększone zapotrzebowanie na tego typu usługi. Oprócz

\footnotetext{
${ }^{9} \mathrm{~Np} . \mathrm{https}: / /$ www.proz.com/forum/machine_translation_mt $/ 290404$ how_do_you_use_mt.html.
} 
tego wskazano na to, że specjalista od postedycji powinien posiadać takie same kwalifikacje jak thumacz zgodnie z normą 17100:2015 oraz dodatkowe kwalifikacje w zakresie pracy z translatorami (np. wykrywanie typowych błędów) i technik redagowania thumaczenia maszynowego.

Niektóre uczelnie oferują kursy postedycji, w tym Instytut Lingwistyki Stosowanej Uniwersytetu Warszawskiego. W Polsce taki kurs dla tłumaczy oferuje również firma Lokalize.pl; a jako jedne z pierwszych opracowały taki kurs kierując się realiami rynku thumaczeniowego firmy TAUS i SDL (Trados). Firma SDL zaznaczyła, że kurs został stworzony, by „sprostać wymaganiom zmieniającego się ryn$\mathrm{ku}^{\prime \prime 10}$. Według założeń tego kursu thumaczenie maszynowe nie ma na celu zastąpienia thumacza; jest to jedynie narzędzie pomocnicze, takie jak program CAT. Na razie nie ma jednak kursów, dotyczących korzystania z tłumaczenia maszynowego $\mathrm{w}$ programach CAT lub jednoczesnego korzystania $\mathrm{z}$ pamięci thumaczeniowej i translatora.

Warto dodać, że istnieje narzędzie służące stricte do edytowania tłumaczenia maszynowego (np. PET) oraz są możliwości związane z postedycją thumaczenia maszynowego w programach CAT: większość programów pozwala na automatyczne przethumaczenie całego tekstu w oparciu o wbudowany translator i dostępne pamięci tłumaczeniowe i następnie jego edycję. Dlatego, jak już zostało wspomniane, niektórzy badacze nie rozróżniają postedycji i tłumaczenia w programie CAT z podglądem tłumaczenia maszynowego ze względu na to, że tłumacz w obu przypadkach ma de facto do czynienia $z$ redagowaniem tłumaczenia. Dotyczy to również przedstawicieli branży: w webinarze „Machine translation and post-editing in the language industry" zorganizowanym w kwietniu 2018 przez kreatorów programu CAT o nazwie Matecat zostało zaznaczone, że korzystając $\mathrm{z}$ tłumaczenia maszynowego w programie Matecat współczesny tłumacz wykonuje postedycję, chociaż kiedyś postedycja była wykonywana przy użyciu odrębnego narzędzia. Taki stan rzeczy wskazuje na to, iż miejsce tłumaczenia w programie CAT z uruchomionym podglądem translatora jeszcze nie zostało określone oraz nie ma jednoznacznego zdania na temat jego powiązania $\mathrm{z}$ postedycją ze względu na relatywną nowoczesność w/w technologii.

\section{Podsumowanie i wnioski}

Podsumowując, chciałabym jeszcze raz podkreślić, że historycznie stworzenie programów CAT jest de facto „produktem ubocznym" próby stworzenia narzędzia, które potrafi wykonać pracę za thumacza - thumacza maszynowego. Tego oczywiście nie udało się zrobić, więc skutkiem było stworzenie programów optymalizujących pracę thumacza przede wszystkim przy pomocy zapamiętywania już przetłumaczonych zdań i ich przechowywanie w tzw. pamięci tłumaczeniowej. Zainteresowanie technologią thumaczenia maszynowego ponownie wzrosło w ostatnich kilkunastu latach, ze względu na rozwój technologii powrócono do idei wspomagania thu-

\footnotetext{
${ }^{10} \mathrm{http}: / /$ www.sdltrados.com/learning/training/post-editing-machine-translation.html.
} 
maczenia przez translator, który w pewnym sensie działa jak pamięć thumaczeniowa. Dzieje się tak dlatego, że thumaczenie maszynowe jest dzisiaj na takim poziomie, na którym może już pomóc tłumaczowi, a nie go rozpraszać. Można więc powiedzieć, że wracamy do pierwotnego pomysłu automatyzacji procesu thumaczenia pisemnego.

Tradycyjnie te dwie technologie (tzn. pamięć thumaczeniowa i thumaczenie maszynowe) były uważane za odrębne ponieważ mają one różne cele: tłumaczenie maszynowe miało zastąpić tłumacza, natomiast pamięć tłumaczeniowa jest tylko narzędziem pomocniczym. Teraz możemy jednak wyciągnąć korzyści z obydwóch. Być może taki tryb pracy niedługo będzie na porządku dziennym.

Jest to jednak relatywnie nowe zjawisko i na chwilę obecną nie ma wytycznych ani kursów korzystania z tej technologii - thumaczenia w programie CAT z uruchomionym silnikiem tłumaczenia maszynowego; nie ma również jednoznacznej definicji czy nazwy tego zjawiska. Uważam więc, że potrzebne są badania w tym kierunku; być może technologia ta jeszcze przez lata będzie istnieć w pracy thumacza, a może nawet zmieni nasze wyobrażenie o tłumaczeniach pisemnych.

\section{Bibliografia}

Bogucki, Ł. (2009), Ttumaczenie wspomagane komputerowo. Warszawa.

O’Brien, S. (2011), Towards Predicting Post-Editing Productivity, (w:) „Machine Translation" 25(3), 197-215.

O'Brien, S. (2012), Translation as Human-Computer Interaction, (w:) „Translation Spaces" 1 (1), 101-122. (URL http://doras.dcu.ie/17541/1/Translation_as_HCI_OBrien.pdf). [Pobrano 09.02.2018].

O'Brien, S./ J. Moorhens (2014), Towards Intelligent Post-Editing Interfaces, (w:) Man vs Machine? Conference Paper. Conference: XXth FIT World Congress, At Berlin, Germany, Volume: 1. (URL https://www.researchgate.net/publication/ 275039972). [Pobrano 03.02.2018].

Bundgaard, K. (2017), (Post-)Editing - A Workplace Study of Translator-Computer Interaction at TextMinded Danmark A/S. Ph.D. thesis. (URL http://vbn.aau.dk/en/publications/postediting--a-workplace-study-of-translatorcomputer-interaction-at-textminded-danmark-as(4b9489a9-df6f-40af-8ba5cad062f50827).html). [Pobrano 10.02.2018].

Christensen, T.P./ A. Schjoldager (2016), Computer-aided translation tools - the uptake and use by Danish translation service providers, (w:) „The Journal of Specialised Translation" 25, 89-105.

Garcia, I. (2009), Beyond Translation Memory: Computers and the Professional Translator, (w:) ,The Journal of Specialised Translation” 12, 199-214.

Guerberof, A.A. (2014), Correlations between productivity and quality when postediting in a professional context, (w:) ,Machine Translation” 28 (3-4), 165-186.

Guerberof A.A./ H. Depraetere/ S. O'Brien (2012), What we know and what we would like to know about post-editing, (w:) ,Revista Tradumàtica” 10, 211-218. 
Guerberof Arenas, A. (2014a), Correlations between productivity and quality when post-editing in a professional context, (w:) „Machine Translation” 28 (3-4), $165-186$.

Hutchins, J. (1998), The Origins of the Translator's Workstation, (w:) „Machine Translation" 13(4), 287-307.

Matecat. Final Report (2014). (URL https://cordis.europa.eu/docs/projects/cnect/8/ 287688/080/reports/001-FinalReportforpublication.pdf). [Pobrano 18.08.2018].

Norma ISO 18587:2017.

Norma PN-EN ISO 17100:2015-06.

Pym, A. (2010), Exploring Translation Theories (Routledge). London and New York.

Teixeira, C.S.C. (2013), Multilingual Systems, Translation Technology and Their Impact on the Translator's Profession, (w): A. Neustein/ J.A. Markowitz, Where Humans Meet Machines. Innovative Solutions for Knotty Natural-Language Problems. New York, 299-314. (URL https://www.researchgate.net/publication/300393619_Multilingual_Systems_Translation_Technology_and_Their_Impact_on_the_Translator's_Profession). [Pobrano 05.02.2018].

Teixeira, C.S.C. (2014), Perceived vs. measured performance in the post- editing of suggestions from machine translation and translation memories, (w:) „Proceedings of the Third Workshop on Post-Editing Technology and Practice", 45-59.

Witczak, O. (2016), Ttumacze kontra maszyny, czyli o thumaczeniu wspomaganym komputerowo, (w:) B. Whyatt $\mathrm{i}$ in., Tłumacz - praktyczne aspekty zawodu. Poznań, 203-234.

\section{Źródla internetowe}

http://www.sdltrados.com/learning/training/post-editing-machine-translation.html. https://ai.googleblog.com/2016/09/a-neural-network-for-machine.html;

https://www.proz.com/forum/machine_translation_mt/290404how_do_you_use_mt.html; 